\title{
CONSUMPTION BEHAVIOR PATTERNS OF MUSLIM STUDENTS ON THE DECISION OF BUYING HALAL CULINARY FAST FOOD IN SURABAYA
}

\author{
A. Fikri Amiruddin Ihsani ${ }^{1)}$, Novi Febriyanti' ${ }^{2}$, \\ ${ }^{1}$ State Islamic University of Sunan Ampel, Surabaya \\ ${ }^{2}$ State Islamic University of Sunan Ampel, Surabaya
}

\begin{abstract}
The purposes of this study was to analyze the consumption behavior patterns of the Postgraduate Students of UINSA Islamic Economics study program as consumers and supporting factors in purchasing halal culinary food products. The research method used was a qualitative research method with a phenomenological approach, this research observes 10 informants of the Postgraduate Students of Islamic Economics Study Program UINSA as fast food consumers KFC Ahmad Yani Surabaya. The results of this study prove that all informants have knowledge of the concepts of consumer behavior and halal products in Indonesia, especially in Surabaya. The students have also applied the pattern of Islamic consumption behavior that is tauhid, fairness, free will, responsibility and halal as well as supporting factors including cultural, social, personal and psychological factors. Knowledge about other supporting factors should be utilized by other consumers for the sustainability and development of perceptions about halal culinary fast food in Surabaya.
\end{abstract}

Keywords: consumption behavior, halal food, fast food.

\section{INTRODUCTION}

Muslim society basically needs consumption to survive where the higher the human needs, the human consumption behavior also increases. Everyone's consumption is different, according to their needs and income level. Different income is the main determinant of consumption of Muslim society. As a Muslim, not all food can be consumed, there are restrictions or rules that must be met (Misbahuddin, 2011: 283-310). In the science of jurisprudence there are rules related to halal and haram food. The rule is that all food in the world is basically halal or permissible. No food is forbidden, except if Allah SWT has determined its prohibition. It is the duty of a Muslim to obey Allah SWT and His Messenger, in this context which is to eat thayyiban's halal products (M Amin, 2011: 2). The order to consume and use thayyiban's halal products is mentioned in His word (Al-Baqarah (2): 168).

Guaranteed halal of a product is an important thing to note, because now with the rapid development of science and technology has given birth to a variety of fast food product businesses. Business competition in the food industry has become commonplace for people (Samori, et al, 2014: 482-486). This is an opportunity for business companies to expand their markets. One opportunity to expand the market is through the food industry. One pattern of the food industry is marked by the growth

*Corresponding author. Email address: fikriamiruddin27@gmail.com 


\section{AFEBI Islamic Finance and Economic Review (AIFER)}

\section{Vol.3 No.2, December 2018}

of the culinary fast food industry or can be called fast food. As we know, franchises have a good reputation for increasing their business worldwide. In addition, the main strategy of the franchise is how to influence the market by examining legal issues regarding halal awareness, habits or lifestyle of consumers, especially on halal products (Presswire, 2014: 72).

According to the Badan Pusat Statistik (BPS, 2019), Indonesia has 237,641,326 residents throughout Indonesia. This means that there is a great opportunity to expand the market in Indonesia. The issue of halal is a major problem for Muslim consumers in Indonesia. Halal information for a product can be conveyed through the halal label given by the Majelis Ulama Indonesia (MUI). Since the 1990s the Majelis Ulama Indonesia (MUI) has taken the initiative to establish the Lembaga Pengkajian Pangan Obat-obatan dan Kosmetika (LPPOM) which purposes to provide halal product guarantees for Muslim consumers through halal certification of a product (MUI, 2016: 49-84). Halal certification is legal certainty for Muslim consumers. This means that consumers get a guarantee that the products they consume are already qualified as halal products. Halal awareness must be considered for culinary industry entrepreneurs, especially fast food, to identify how many lifestyles consumers know whether the product is safe or not. (Prabowo, et al: 2015, 268-291).

In the era of modernization as it is today, the challenge of developing practical and instant lifestyles that affect almost all populations in the world. Instant lifestyle is a lifestyle that is fast, precise, and effective. According to industry, the challenge is the most important factor in supporting the success of the business world. Supporting competition will bring great benefits for consumers who then respond to the franchise (Yolanda Hani, 2015: 571). One of the franchises that attracts so many consumers is Kentucky Fried Chicken (KFC) Ahmad Yani Surabaya by providing halal culinary fast food for the fast-paced Muslim community (KFC, 2019). These consumers are in the form of individual, group, and organizational behavior that selects, buys and uses products to satisfy their needs and desires (Ahmad Yani, 2017: 45).

Consumption behavior is an action that is directly involved in getting, consuming and consuming a product including the decision process that precedes the action. The decision is in the form of purchases made by everyone at any time and place (Tatik Suryani, 2013: 4). Buying decisions are supported by several factors, these factors encourage that requires everyone to be able to get the products needed and desired. Factors that support purchasing decisions by consumption behavior are cultural, social, personal and psychological factors (Daryanto, Ismanto, 2014: 83). That way the level of halal culinary fast food has a relationship with consumer consumption behavior patterns interesting to study. Diversity of consumer consumption behavior patterns in buying a product is supported by various factors both internal and external. 


\section{LITERATURE STUDY}

\subsection{Islamic Consumption Behavior}

Consumption behavior is the study of how individuals, groups, and organizations choose, buy, use, and how goods, services, ideas, or experiences to satisfy their needs and desires (Tatik Suryani, 2013: 4). Efforts made by consumers to obtain goods and services can be preceded by efforts to search for information, can be through the internet or the surrounding community. If the product is high risk, then consumers will look for more information to avoid mistakes in decision making. If consumers believe in the benefits of a superior product, consumers will buy and consume these products. Behavior carried out between consumers will certainly vary according to consumer conditions, internal and external situations and conditions that support it (Bilson Simamura, 2004: 11).

Thus the fulfillment of one's consumption should be based on the principles that have been determined in the teachings of Islamic economics. Because the pattern of consumption behavior is essentially issuing something in order to meet the needs of an individual or group. (Muhammad Muflih, 2006: 16) The pattern of consumption behavior will be discussed more clearly as follows:

1. Tauhid

A person who has a soul of tauhid will not be able to do God's prohibition, because in economics it is used as mediation in meeting human needs, both primary needs, secondary needs and complementary needs, involving interactions between metaphysical and physical aspects, because economic activities (business) in the perspective of tauhid is based on the principles in Islam (Tim Sembilan, 2004: 85-86).

2. Fairness

Fair means equal (average), commensurate size (measurement), balance in conducting economic transactions carried out. With regard to justice it has four parts namely the creation of a balanced one, equality and interpretation of all forms of discrimination, the maintenance of individual rights and the granting of rights to everyone who is entitled to receive, as well as maintaining the right for continued existence (Muhammad, 2005: 167).

3. Free Will

Humans are free will creatures but this freedom does not mean that humans are independent of qadha and qadhar. Qadha and qadhar are cause and effect based on literacy, perceptions and attitudes that humans do in economic activities. Furthermore, humans must have free will by possessing simple qualities including shame, calm, generous, satisfied, loyal and noble (Sumarin, 2013: 85).

4. Responsibility

The freedom to determine the choice above is attached to the mandate and responsibility, because humans have been given the intellect to think about 


\section{AFEBI Islamic Finance and Economic Review (AIFER)}

\section{Vol.3 No.2, December 2018}

what is good and what is bad, what is maslahah and which interpretations are beneficial and mudharat. Because of that freedom, it is logical (natural) if humans must be responsible for all economic behavior of their own choosing (Sutisna, 2003: 205).

5. Halal

The halal of a consumer good is an antipization of the evils that are caused by the good. Halal refers to everything that is good from a case that is permitted, permitted and justified according to Islamic sharia law. That way, halal products are food and drinks that can be consumed by Muslim communities, while food and drinks that are forbidden by Islam are not allowed to be consumed by Muslim communities (Said, et al, 2008: 60).

\subsection{Halal Food}

The term halal in the Qur'an means permissible (John L, 2002: 143). Muhammad ibn Ali al-Shaukanī believes that it is said to be halal because it has been detached and the detached knot or prohibited ties are prevented. While the word halal in the encyclopedias of Islamic law, that is, anything that causes someone not to be punished if using it, can be interpreted as something that can be done according to the law of syara' (Muhammad, 1996: 505-506). Halal food is food that is allowed for Muslim communities to eat. Islam justifies everything that is good. While forbidden food is forbidden for Muslim communities to eat (Muchtar ali, 2016: 292). Basically, all food in this world is halal to be consumed, unless there is a proposition that prohibits either from the Qur'an or Hadith. In accordance with the following fiqh rules: "The law of origin is something that is permissible until there is an argument that forbids it (forcing it or forbid it)."

The purpose of the rule is that the original law of everything created by Allah SWT is permissible and permissible, unless there is nașh șahịih which shows its prohibition. In other words, if there is no nașh șahịih or there is no clear indication of its prohibition, then something is still in its original law, that is mubah (Abdul A, 1996: 32). In Islam consuming food does not only promote the concept of halal, but also tayyiban. In accordance with the word of Allah SWT in surah Al-Maidah verse 88:"And eat halal food again that is good from what Allah SWT has blessed you with, and fear the God whom you believe in Him."

The verse explains that all Muslims living on this earth must seek sustenance, the halāl and țayyib. They must eat halal food and avoid eating dirty food and food that is prohibited in Islam. So it will not damage their bodies and lives. Therefore, the concept of halālan țayyiban means usefulness, which consists of quality, cleanliness and safety for all the lives of Muslims. The word of tayyib in Arabic has a good meaning, so good food for consumption is still fresh and protected from disease. As Muslims, in eating daily food should not be 
careless. The food we eat must be halālan țayyiban, which means halal and good food according to Islamic sharia law (Abu Al-Husain, 1994: 487).

\section{RESEARCH METHODOLOGY}

The research method used was a qualitative research method with a phenomenological approach, this research observes 10 informants of the Postgraduate Students of Islamic Economics Study Program UINSA as fast food consumers KFC Ahmad Yani Surabaya. In this study the author focuses on the results of data collection obtained directly from the informants and sources who have been determined (Sugiyono, 2019: 293). The research will be purposed at UINSA Postgraduate students and focused on all of Islamic Economics study programs related to Islamic consumption behavior patterns and factors supporting purchasing decisions in terms of the halal culinary fast food level. The formulation of the problem in this research is how the consumption behavior patterns of UINSA Postgraduate students as consumers in the decision to buy products at KFC Ahmad Yani Surabaya restaurant, and what are the dominant factors as supporters in the decision to buy products at KFC Ahmad Yani Surabaya restaurant. The benefit of this research is to know and have a clear picture, in addition to enriching insights and knowledge, especially relating to consumer behavior in relation to buying decisions.

\section{RESULT}

\subsection{Islamic Consumption Behavior}

Limitation of consumption in Islam does not only pay attention to aspects of halal-haram, but also includes what is considered is good, suitable, clean, not disgusting, prohibition of Islam and prohibition to boast (Khotib, 2019). Because the calculation of the quantity and quality of consumption has an impact on income, consumption and savings should be determined on the basis of justice so that it does not overstep the boundaries by being wasteful (tabzir) or miserly (bakhil). Behavioral consumption of students of the Islamic Economics Postgraduate study program in consuming halal culinary fast food products has several patterns, including:

1. Tauhid

The principle of tauhid becomes the main foundation for every Muslim in carrying out his activities including economic activities (Syaikul Fikri, 2019). The Postgraduate Students of Islamic Economics Study Program UINSA as consumers when they consume will have to know the knowledge about the products to be consumed at KFC Ahmad Yani Surabaya. The laws relating to halal culinary fast food whether something is halal or haram both in terms of the substance, process, and purpose. As a consequence of the aqeedah and knowledge that has been known about Islamic consumption, then as a consumer at KFC Ahmad Yani as a halal culinary fast food producer consumes only halal and away from haram and syubhat (Muslih, 2019). 


\section{AFEBI Islamic Finance and Economic Review (AIFER)}

\section{Vol.3 No.2, December 2018}

2. Fairness

As consumers in consumption should not cause tyranny, must be in the corridor of religious rules or laws and uphold propriety or goodness. By obeying the teachings of Islam there is no danger or sin when consuming halal products provided by Allah SWT. As long as consuming is an effort to meet the needs that bring benefits to life and the role of humans to increase devotion to Allah SWT, then Allah SWT will give justice in the form of His grace to Muslim's consumption (Kiky Dzakiyah, 2019). Is the most important part of justice with the aim of mutual benefit to the Postgraduate Students of Islamic Economics Study Program UINSA as consumers with KFC Ahmad Yani Surabaya as halal culinary fast food producers. The implications of this principle are as follows (Nur Aini, 2019):

a. Fullfillment of basic needs.

b. Halal sources of income.

c. Equitable distribution of income and wealth.

d. Growth and stability

3. Free Will

The consumption action is carried out every day by anyone including students of the Postgraduate Students of Islamic Economics Study Program UINSA as consumers. The goal is to get the highest satisfaction and reach the level of prosperity in the sense of fulfilling various needs, one of which is halal culinary fast food at KFC Ahmad Yani Surabaya, which is much loved. The level of consumption gives a picture of the level of prosperity of a person or students of the Postgraduate Students of Islamic Economics Study Program UINSA as consumers (Ummi Kulsum, 2019). However, this excessive attitude does not contain meaning beyond natural needs and tends to discourage passions or is otherwise too stingy so that it tortures oneself.

4. Responsibility

In the end, the consumption of the Postgraduate Students of Islamic Economics Study Program UINSA as consumers as a whole is framed by morality contained in Islam so that it does not merely fulfill all needs. Consumption behavior patterns in Islam have been prescribed so as not to live lavishly, not to try forbidden work in order to become a reference in the development of the Islamic economic system (Siti Fatimah, 2019). Human awareness of the behavior or actions, whether intentional or unintentional to the behavior patterns of halal culinary fast food consumption at KFC Ahmad Yani Surabaya. Responsibility also means acting as an expression of awareness of the obligation.

5. Halal

Consumption is not an unlimited activity, but it is also limited by the nature of halal and haram which has been outlined by the Islamic syariah law. There are UINSA Islamic Economics postgraduate students with a rational consumption behavior pattern (mustahlik al-aqlani) always spending income on various types of goods that suit their physical and spiritual needs 
(Muaddin, 2019). KFC Ahmad Yani as a producer of halal culinary fast food has already been seen, namely food that is not obtained from stealing, pillaging, cheating, or corruption. There are several benefits of eating halal food, especially for bodily health. Some of them are as follows (Khotib 2019):

a. Stay away from sources of disease

b. Maximizing the power source

c. Keep your heart and mind

d. Maintain morals

e. Get the pleasure of Allah SWT

f. Lead to His heaven

g. Repairing offspring

\subsection{Supporting Factors of Consumption Behavior}

Regarding the factors that support purchasing decisions in the consumption patterns of students of the Postgraduate Students of Islamic Economics Study Program UINSA are based on cultural, social, personal and psychological factors. Further explanation is as follows:

1. Cultural Factors

Culture is the most basic supporting factor of desire and behavior to get what is developing. Like halal culinary fast food at KFC Ahmad Yani, which has a lot of interest among students of the Postgraduate Students of Islamic Economics Study Program UINSA. The relationship between the purchasing decision of students of the the Postgraduate Students of Islamic Economics Study Program UINSA is that culture is used as a reference for someone to make a purchase. So that culture fully supports the purchasing decisions in consumption behavior patterns. Halal culinary fast food is very popular because of the rise of instant and fast human life, coupled with the location of the restaurant that is so close in front of the UINSA Surabaya (Mohammad Septyan, 2019).

2. Social Factors

a. Group Factors

The meaning of a group of students in the Postgraduate Students of Islamic Economics Study Program UINSA are friends, friends provide direct support to each person. That is because if someone often interacts with his friends indirectly all input and information from his friend tends to be taken into consideration to make purchasing decisions in consumption behavior patterns (Shelvyna Rikantasari, 2019). The friend factor which is considered as one of the factors by showing more and more friends often inviting or persuading to consume halal culinary fast food, then the person the greater the purchase decision to consume it.

b. Family Factors

The meaning of family in the Postgraduate Students of Islamic Economics Study Program UINSA is parents, parents are included in the primary group who are able to support any consumption behavior patterns 


\section{AFEBI Islamic Finance and Economic Review (AIFER)}

\section{Vol.3 No.2, December 2018}

of halal culinary fast food purchases in KFC Ahmad Yani Surabaya. Parents are one of the reference sources of reference and input sources that can provide important and valuable information about the attributes of the product you want to buy. It can be said that parents are merely a reference by providing input but the purchasing decision that ends consumption is still decided by the individual concerned (Muslih, 2019).

c. Role and Status Factors

The role consists of activities that are expected to be undertaken by students of the Postgraduate Students of Islamic Economics Study Program UINSA according to other students who are nearby. Each role carries a status that reflects the award given by students. That means someone tends to buy products according to their status among students around. Like students who want a product that can be immediately obtained, by entrusting to one student to regulate the course of consumption to related students (Muaddin 2019).

3. Personal Factors

a. Age Factor

The more age, the maturity level and maturity of a person will be more mature in thinking and behaving. In terms of trust, students of the Postgraduate Students of Islamic Economics Study Program UINSA are more trusted than people who are not equal in terms of education on campus (Khotib, 2019). Associated with purchasing decisions in consumption behavior patterns, a person whose age is more mature in terms of science can be considered and be more careful before deciding to consume an item, compared to someone who is younger in age and thought that tends to decide to consume an item based on ego and aspects price of an item.

b. Job Factor

The students of the Postgraduate Students of Islamic Economics Study Program UINSA have a variety of activities, the activities are more suited to their respective passions. Evidenced by the number of students who have jobs besides college. Halal culinary fast food itself is very much needed by workers because one food product is very easy to find or find and obtain, so it will not interfere with the working hours of students of the Postgraduate Students of Islamic Economics Study Program UINSA who are already working (Kiky Dzakiyah, 2019).

c. Economic Status Factors

KFC Ahmad Yani Surabaya always said that the quality of the product was in accordance with the reality seen, while students did not defect the expected product. This is commensurate with the economic needs of students of the Postgraduate Students of Islamic Economics Study Program UINSA as consumers that the quality of halal food products with brands and which have been widely recognized and assessed well after 
purchase as a factor that strongly reflects the quality of the individual economy. The better the pattern of student consumption behavior on a halal food product, the better consumers' perception of product quality (Ummi Kulsum, 2019).

d. Lifestyle Factors

The Postgraduate Students of Islamic Economics Study Program UINSA as consumers in buying food products are to fulfill their hunger and lifestyle. Consideration of hunger and lifestyle becomes the main consideration of KFC Ahmad Yani Surabaya as a producer of fast food. Another factor which is the motivation or reason for the Postgraduate Students of Islamic Economics Study Program UINSA as consumers in buying food products is due to the influence of advertising. This is because KFC Ahmad Yani Surabaya promotes its products through advertisements such as print media in the form of billboards, banners or pamphlets and electronic media in the form of television and cyberspace, so consumers are attracted and try advertised food products (Siti Fatimah, 2019).

4. Psychological Factors

a. Motivation

Product display, name, symbol or label, advertisement, are closely related to the brand image of KFC Ahmad Yani Surabaya as the producer. Brand image refers to the motivation of the Postgraduate Students of Islamic Economics Study Program UINSA as consumers of a product identity. On the other hand, KFC Ahmad Yani Surabaya as the producer always performs customer satisfaction and comfort in terms of service because service is a priority (Nur Aini, 2019). Students who are satisfied with the quality of the products obtained and good service from KFC Ahmad Yani Surabaya, then consumers will always refer to other prospective customers to conduct transactions in the same place.

b. Knowledge

They have the knowledge of science in consumption as consumers that the products sold at KFC Ahmad Yani Surabaya meet the legal requirements of halal and thayyib. And the attitude of resignation shown by KFC Ahmad Yani Surabaya is always producing good quality products to be traded to consumers every day. Add to this the acknowledgment of the halal status of a product issued by LPPOM MUI (Lembaga Pengkajian Pangan Obat-obatan dan Kosmetik Majelis Ulama Indonesia). This adds to the position that is centered on the guarantee of halal products (Novia Dwi, 2019).

c. Confidence

The Postgraduate Students of Islamic Economics Study Program UINSA as consumers and KFC Ahmad Yani Surabaya as halal culinary fast food producers do not do negative thinking or prejudice. the Postgraduate Students of Islamic Economics Study Program UINSA as consumers and KFC Ahmad Yani Surabaya as producers can fulfill their 


\section{AFEBI Islamic Finance and Economic Review (AIFER)}

\section{Vol.3 No.2, December 2018}

rights and obligations. Consumers have the right to choose the product to be purchased, as well as the producer also has the right to explain the product it sells, as well as provide promo prices or packages to consumers with an appropriate offer. If both of them agree on the price of the product offered, then both of them make a purchase by agreement of the sale and purchase transaction agreement (Shelvyna Rikantasari, 2019).

\section{DISCUSSION}

Consumption behavior is an activity that is closely related to the process of purchasing an item or service. Consumption behavior underlies consumers to make purchasing decisions (Tatik Suryani, 2013: 3). When deciding to buy an item or a product, of course the consumer always thinks first of the item to be purchased. Starting from the price, quality, function or usefulness of the goods, and so forth. The activity of thinking, considering, and questioning goods before buying constitutes or belongs to consumption behavior. Consumption behavior has several patterns in purchasing decisions to be made ((Bilson Simamura, 2004: 11).

First is tauhid, a person who has a soul of tauhid will not be able to do God's prohibition, because in economics it is used as mediation in meeting human needs, both primary needs, secondary needs and complementary needs, because economic activities (business) in the perspective of tauhid is based on the principles in Islam (Tim Sembilan, 2004: 85-86). The Postgraduate Students of Islamic Economics Study Program UINSA as consumers when they consume will have to know the knowledge about the products to be consumed at KFC Ahmad Yani Surabaya. The laws relating to halal culinary fast food whether something is halal or haram both in terms of the substance, process, and purpose. As a consequence of the aqeedah and knowledge that has been known about Islamic consumption, then as a consumer at KFC Ahmad Yani as a halal culinary fast food producer consumes only halal and away from haram and syubhat.

Second is fairness, fair means equal (average), commensurate size (measurement), balance in conducting economic transactions carried out (Muhammad, 2005: 167). As consumers in consumption should not cause tyranny, must be in the corridor of religious rules or laws and uphold propriety or goodness. By obeying the teachings of Islam there is no danger or sin when consuming halal products provided by Allah SWT. As long as consuming is an effort to meet the needs that bring benefits to life and the role of humans to increase devotion to Allah SWT, then Allah SWT will give justice in the form of His grace to Muslim's consumption (Kiky Dzakiyah, 2019). Is the most important part of justice with the aim of mutual benefit to the Postgraduate Students of Islamic Economics Study Program UINSA as consumers with KFC Ahmad Yani Surabaya as halal culinary fast food producers (Nur Aini, 2019).

Third is free will, humans are free will creatures but this freedom does not mean that humans are independent of qadha and qadhar. Qadha and qadhar are cause and effect based on literacy, perceptions and attitudes that humans do in economic activities (Sumarin, 2013: 85). The consumption action is carried out every day by 


\section{CONSUMPTION BEHAVIOR PATTERNS OF MUSLIM STUDENTS ON THE DECISION OF BUYING HALAL CULINARY FAST FOOD IN SURABAYA}

anyone including students of the Postgraduate Students of Islamic Economics Study Program UINSA as consumers. The goal is to get the highest satisfaction and reach the level of prosperity in the sense of fulfilling various needs, one of which is halal culinary fast food at KFC Ahmad Yani Surabaya, which is much loved. The level of consumption gives a picture of the level of prosperity of a person or students of the Postgraduate Students of Islamic Economics Study Program UINSA as consumers (Ummi Kulsum, 2019).

Fourth is responsible, the freedom to determine the choice above is attached to the mandate and responsibility, because humans have been given the intellect to think about what is good and what is bad, what is maslahah and which interpretations are beneficial and mudharat (Sutisna, 2003: 205). In the end, the consumption of the Postgraduate Students of Islamic Economics Study Program UINSA as consumers as a whole is framed by morality contained in Islam so that it does not merely fulfill all needs. Consumption behavior patterns in Islam have been prescribed so as not to live lavishly, not to try forbidden work in order to become a reference in the development of the Islamic economic system (Siti Fatimah, 2019). Human awareness of the behavior or actions, whether intentional or unintentional to the behavior patterns of halal culinary fast food consumption at KFC Ahmad Yani Surabaya. Responsibility also means acting as an expression of awareness of the obligation.

Fifth is halal, the halal of a consumer good is an antipization of the evils that are caused by the good. Halal refers to everything that is good from a case that is permitted, permitted and justified according to Islamic sharia law. That way, halal products are food and drinks that can be consumed by Muslim communities, while food and drinks that are forbidden by Islam are not allowed to be consumed by Muslim communities (Said, et al, 2008: 60). Consumption is not an unlimited activity, but it is also limited by the nature of halal and haram which has been outlined by the Islamic syariah law. There are UINSA Islamic Economics postgraduate students with a rational consumption behavior pattern (mustahlik al-aqlani) always spending income on various types of goods that suit their physical and spiritual needs (Muaddin, 2019).

The pattern of consumption behavior refers to the selection, acquisition and consumption of goods and services to meet their needs. There are various processes involved in consumption behavior. Initially, consumers try to find what products they want to consume, then only choose products that promise greater utility. After choosing a product, the consumer makes an estimate of the funds available to buy it. Finally, consumers look at current commodity prices and make purchasing decisions on which products to consume. Meanwhile, there are several factors that support patterns of consumption behavior such as cultural, social, personal and psychological factors.

Cultural factors, culture is also a way to act and think in accordance with the experiences that have been had. Culture is the most basic supporting factor of desire and behavior to get what is developing. Like halal culinary fast food at KFC Ahmad Yani, which has a lot of interest among students of the Postgraduate Students of Islamic Economics Study Program UINSA. The relationship between the purchasing 


\section{AFEBI Islamic Finance and Economic Review (AIFER)}

\section{Vol.3 No.2, December 2018}

decision of students of the Postgraduate Students of Islamic Economics Study Program UINSA is that culture is used as a reference for someone to make a purchase. So that culture fully supports the purchasing decisions in consumption behavior patterns. Halal culinary fast food is very popular because of the rise of instant and fast human life, coupled with the location of the restaurant that is so close in front of the UINSA Surabaya (Mohammad Septyan, 2019).

Social factors are group, family, role and status queues. The meaning of a group of students in the Postgraduate Students of Islamic Economics Study Program UINSA are friends, friends provide direct support to each person. That is because if someone often interacts with his friends indirectly all input and information from his friend tends to be taken into consideration to make purchasing decisions in consumption behavior patterns. The meaning of family in the Postgraduate Students of Islamic Economics Study Program UINSA is parents, parents are included in the primary group who are able to support any consumption behavior patterns of halal culinary fast food purchases in KFC Ahmad Yani Surabaya. The meaning of role and status consists of activities that are expected to be undertaken by students of the Postgraduate program of Islamic Economics in UINSA according to other students who are nearby. Each role carries a status that reflects the appreciation given by students.

Personal factors include factors of age, profession, economic status and lifestyle. The more age, the maturity level and maturity of a person will be more mature in thinking and behaving. In terms of trust, students of the Postgraduate Students of Islamic Economics Study Program UINSA are more trusted than people who are not equal in terms of education on campus. Halal culinary fast food itself is very much needed by workers because one food product is very easy to find or find and obtain, so it will not interfere with the working hours of students of the Postgraduate Students of Islamic Economics Study Program UINSA who are already working. Because the Postgraduate Students of Islamic Economics Study Program UINSA as consumers in buying food products are to fulfill their hunger and lifestyle.

Psychological factors have motivational factors, knowledge and beliefs. Product display, name, symbol or label, advertisement, are closely related to the brand image of KFC Ahmad Yani Surabaya as the producer. Brand image refers to the motivation of students of the Postgraduate program of Islamic Economics UINSA as consumers of a product identity. Taking into account celebrity endorsement in advertising and the price offered can affect a positive brand image on consumer purchasing decisions. They have the knowledge of science in consumption as consumers that the products sold at KFC Ahmad Yani Surabaya meet the legal requirements of halal and thayyib. Add to this the acknowledgment of the halal status of a product issued by LPPOM MUI (Lembaga Pengkajian Pangan Obat-obatan dan Kosmetik Majelis Ulama Indonesia). This adds to the position that is centered on the guarantee of halal products.

Thus the pattern of consumption behavior of Muslim students and supporting factors in the decision to purchase halal culinary fast food in Surabaya. It should 


\section{CONSUMPTION BEHAVIOR PATTERNS OF MUSLIM STUDENTS ON THE DECISION OF BUYING HALAL CULINARY FAST FOOD IN \\ SURABAYA}

always be based on the teachings that have been determined in Islamic Sharia law, because consumption is essentially issuing something in order to meet needs.

\section{CONCLUSION}

Based on the results of the analysis and discussion, it can be concluded the research patterns of consumption behavior of students of the Postgraduate Students of Islamic Economics Study Program UINSA on halal culinary fast food in Surabaya based on tauhid, fairness, free will, responsibility and halal as well as supporting factors including cultural, social factors, personal and psychological for purchasing decisions in the consumption patterns of students of the Postgraduate Students of Islamic Economics Study Program UINSA as consumers on purchasing halal food products, precisely halal culinary fast food at KFC Ahmad Yani Surabaya.

\section{References}

Aini, Nur. 2019. "Consumption behavior of Halal Culinary Fast Food". Results of personal interviews: Surabaya.

Ali, Muchtar. (2016). “Konsep Makanan Halal Dalam Tinjauan Syariah dan Tanggung Jawab Produk Atas Produsen Industri Halal”. Ahkam. 16(2), 292.

Amin, M. (2011). "Keharaman Babi yang Bersifat Mutlak LP POM MUI”. Jurnal Halal: Menentramkan Umat. 8(4), 2.

Badan Pusat Statistik. (2010). "Penduduk Indonesia menurut Provinsi 1971, 1980, 1990, 1995, 2000 dan 2010”, https://www.bps.go.id/statictable/2009/02/20/1267/pendudukindonesia-menurut- provinsi-1971-1980-1990-1995-2000-dan-2010.html, accessed on March 20, 2019.

Dahlan, Abdul Azis. (1996). Ensiklopedi Hukum Islam. Cet. ke-1. Jakarta: Ikhtiar Baru van Hoeve.

Dzakiyah, Kiky. 2019. "Consumption behavior of Halal Culinary Fast Food”. Results of personal interviews: Surabaya.

Esposito, John L. (2002). Ensiklopedi Oxford, Dunia Islam Modern. Terj. Eva YN. Bandung: Mizan.

Fatimah, Siti. 2019. "Consumption behavior of Halal Culinary Fast Food”. Results of personal interviews: Surabaya.

Fikri, Syaikhul. 2019. "Consumption behavior of Halal Culinary Fast Food". Results of personal interviews: Surabaya.

Kentucky Fried Chicken (KFC) Indonesia. http://www.kfcindonesia.com/, accessed on March 20, 2019. 


\section{AFEBI Islamic Finance and Economic Review (AIFER)}

\section{Vol.3 No.2, December 2018}

Khotib. 2019. "Consumption behavior of Halal Culinary Fast Food". Results of personal interviews: Surabaya.

Kulsum, Ummi. 2019. “Consumption behavior of Halal Culinary Fast Food”. Results of personal interviews: Surabaya.

Majelis Ulama Indonesia. (2016). “Daftar Belanja Produk Halal”. Jakarta: LPPOM MUI.

Misbahuddin. (2011). “Konsep Islam dalam al-Quran”. Al-Ulum. 11(2), 283-310.

Muaddin. 2019. "Consumption behavior of Halal Culinary Fast Food". Results of personal interviews: Surabaya.

Muflih, Muhammad. (2006). Perilaku Konsumen dalam Perspektif Ekonomi Islam. Jakarta: PT RajaGrafindo Persada.

Muhammad. (2005). Ekonomi Mikro dalam Perspektif Islam. Yogyakarta: BPFE.

Muslih. 2019. "Consumption behavior of Halal Culinary Fast Food". Results of personal interviews: Surabaya.

Nastiti, Novia Dwi. 2019. "Consumption behavior of Halal Culinary Fast Food". Results of personal interviews: Surabaya.

Prabowo, et al. (2015). Revealing factors hindering halal certification in East Kalimantan Indonesia. Journal of Islamic Marketing. 6(2), 268-291.

Presswire, M2. (2014). Consumer Foodservice by Location in Indonesia. Canada: Bharat Book Bureau.

Rikantasari, Shelvina. 2019. "Consumption behavior of Halal Culinary Fast Food". Results of personal interviews: Surabaya.

Said, Syihabudin \& Ma'zumi. (2008). Falsafah dan Perilaku Ekonomi Islam. Jakarta: Diadit Media.

Samori, et al. (2014). "Memahami Pengembangan Standar Makanan Halal: Saran untuk Penelitian Masa Depan". Jurnal Internasional Ilmu Sosial dan Kemanusiaan. 4(6), 482-486.

Sembilan, Tim. (2004). Tafsir Maudhu’i, Al-Muntaha. Yogyakarta: Pustaka Pesantren.

Septyan, Mohammad. 2019. "Consumption behavior of Halal Culinary Fast Food". Results of personal interviews: Surabaya.

Setyabudi, Daryanto \& Ismanto. (2014). Konsumen dan Pelayanan Prima. Yogyakarta: Gava Media.

Simamura, Bilson. (2004). Riset Perilaku Konsumen. Jakarta: Gramedia Pustaka Utama. 


\section{CONSUMPTION BEHAVIOR PATTERNS OF MUSLIM STUDENTS ON \\ THE DECISION OF BUYING HALAL CULINARY FAST FOOD IN}

SURABAYA

Sugiyono. (2019). Metode Penelitian Kuantitatif, Kualitatif, dan R\&D. Bandung: Alfabeta.

Sumarin. (2013). Ekonomi Islam: Sebuah Pendekatan Ekonomi Mikro Perspektif Islam. Yogyakarta: Graha Ilmu.

Suryani, Tatik. (2013). Perilaku Konsumen. Yogyakarta: Graha Ilmu.

Sutisna. (2003). Perilaku Konsumen dan Komunikasi Pemasaran. Bandung: PT Remaja Rosdakarya.

Yani, Ahmad. (2017). Label Halal dan Konsumen Cerdas dalam Perdagangan Pasar Bebas. Jurnal Gea. 7(2), 45.

Yolanda Hani Putriani. (2015). Pola Perilaku Konsumsi ditinjau dari Tingkat Religiusitas. JESTT. 2(7), 571.

Zakariya, Abu Al-Husain Ahmad ibn Faris. (1994). Mu'jam Al Maqayis fiy Al-Lughah. Beirut: Dar Al-Fikr. 